\title{
Reminder System dan Monitoring Proyek untuk Penilaian Kinerja Karyawan Berbasis Web
}

\author{
Nikko Putra Riyanto ${ }^{[1]}$, Tarimantan Sanberto Saragih ${ }^{[2]}$ \\ Fakultas Ilmu Komputer, Universitas Mercu Buana ${ }^{[1],[2]}$ \\ 41815110093@student.mercubuana.ac.id ${ }^{[1]}$, tarimantan.saragih@mercubuana.ac.id ${ }^{[2]}$
}

\begin{abstract}
Abstrak - Monitoring proyek merupakan suatu prosedur yang diperlukan untuk memastikan proyek yang sedang dikerjakan dapat dikelola dengan efektif dan dapat diselesaikan tepat waktu. Permasalahan yang ada saat ini, terdapat beberapa proyek yang sedang dikerjakan kerap mengalami keterlambatan serta proses pelaporan pekerjaan proyek yang tidak terintegrasi dengan data pengembangan proyek pada sistem berjalan menyebabkan pencarian informasi historical aktivitas proyek sulit untuk dilakukan. Selain itu perhitungan penilaian kinerja karyawan masih dilakukan dengan cara konvensional menggunakan Microsoft Excel, sehingga memakan waktu cukup lama dalam pembuatannya. Oleh karena itu, pada penelitian ini bertujuan untuk membuat sebuah sistem reminder dan monitoring aktivitas pengembangan proyek yang juga dapat digunakan untuk penilaian kinerja karyawan berbasis web, sehingga diharapkan dapat mempermudah proses monitoring dan pelaporan aktifitas proyek serta mempercepat proses penilaian kinerja karyawan. Metode penelitian yang dilakukan merupakan studi kasus dengan menggunakan metode System Development Life Cycle (SDLC) Waterfall dan menggunakan perancangan diagram UML.
\end{abstract}

Kata Kunci - sistem informasi; monitoring proyek; penilaian kerja; waterfall

\section{PENDAHULUAN}

PT Jaguar Technology merupakan salah satu IT System Integrator terkemuka di Indonesia yang memiliki jumlah pelanggan cukup banyak dari mulai bidang keuangan, telekomunikasi, pemerintahan, kesehatan, manufaktur, migas, ritel sampai distribusi. Dengan banyaknya jumlah pelanggan, maka proyek yang dikerjakan pun cukup banyak. Manajemen proyek merupakan penerapan ilmu pengetahuan, keterampilan, peralatan serta teknik yang terdapat didalam aktivitas proyek untuk memenuhi kebutuhan proyek.[1]. Manajemen proyek memiliki serangkaian aktivitas yang terdiri dari kegiatan perencanaan, penjadwalan dan pengendalian proyek. Sebuah proyek memiliki serangkaian kegiatan yang harus diawasi siapa yang mengerjakan dan bagaimana perkembangan dari proyek tersebut, apakah berjalan lancar, tersendat atau bahkan terhenti. Selain itu, di dalam pengerjaan proyek juga harus dapat diketahui apa saja yang menyebabkan proyek tersebut menjadi tersendat atau terhenti. Dalam mengantisipasi hal tersebut maka sangat diperlukan pengawasan proyek yang baik agar proyek yang sedang dikerjakan dapat dikelola dengan efektif dan dapat diselesaikan tepat waktu. Tepat waktu dalam mengerjakan sebuah proyek merupakan salah satu point utama dari segi bisnis, karena hal ini dapat menjaga hubungan dan juga kepercayaan dari konsumen[2]
Monitoring atau pengawasan merupakan suatu proses yang dilakukan untuk mengkaji pekerjaan yang sudah dilaksanakan untuk dinilai maupun dikoreksi dengan maksud agar pelaksanaan sesuai dengan rencana[3]. Proses pengawasan proyek yang saat ini dilakukan pada PT. Jaguar Technology menggunakan sebuah sistem berbasis web yang digunakan untuk melakukan pencatatan data proyek dan perkembangan status terakhir dari sebuah proyek. Namun berdasarkan pengamatan yang dilakukan langsung pada PT. Jaguar Technology, sistem tersebut belum dapat digunakan secara maksimal dalam mendukung proses pengawasan data proyek yang ada. Pencatatan data proyek tidak bisa dilakukan secara rinci karena terdapat keterbatasan isian kolom data pada sistem tersebut sehingga pengisian detail informasi proyek seperti batas akhir aktivitas proyek, penugasan Person in Charge (PIC) proyek maupun informasi perkembangan proyek dilakukan pada kolom detail proyek. Selain itu didalam sistem tersebut juga tidak ada sistem reminder kepada PIC proyek manakala terdapat proyek yang mendekati atau bahkah sudah melewati batas akhir pengerjaan, sehingga diperlukan pengawasan secara manual terhadap batas akhir dari sebuah proyek.

Dalam mengerjakan sebuah proyek, karyawan diwajibkan melakukan pelaporan aktivitas pekerjaan yang dilakukan. Karyawan di perusahaan IT memainkan peran yang sangat penting dalam kelangsungan hidup perusahaan. Karyawan merupakan komponen kunci dari setiap sistem yang berhasil[4]. Sehingga pengawasan terhadap aktivitas karyawan juga penting untuk dilakukan. Pelaporan aktivitas proyek yang dilakukan saat ini tidak terintegrasi dengan data proyek pada sistem berjalan, karena proses pelaporan aktivitas pekerjaan karyawan dilakukan diluar sistem dengan menggunakan aplikasi Microsoft Excel. Hal tersebut menyebabkan perlunya proses verifikasi dan rekapitulasi data secara manual yang memakan waktu lama dalam menyediakan bahan evaluasi manajemen untuk melakukan penilaian kinerja karyawan. Penilaian kinerja merupakan salah satu kegiatan yang dilakukan untuk menilai kinerja dari seseorang yang berkaitan dengan pencapaian tujuan, kegiatan, output dan target pekerjaan selama periode waktu tertentu[5]. Selain itu penyediaan informasi seperti data historical aktivitas pekerjaan yang telah dilakukan didalam sebuah proyek juga sulit untuk dilakukan karena data pelaporan aktivitas proyek tiap-tiap karyawan berada didalam data Microsoft Excel yang berbeda-beda dan terpisah berdasarkan periode pelaporan yang dilakukan. 
Berdasarkan permasalahan yang telah dijabarkan tersebut, maka PT. Jaguar Technology membutuhkan sebuah sistem yang dapat digunakan dalam membantu proses pengawasan proyek yang sedang dilakukan serta dapat mengintegrasikan data proyek dengan data pelaporan aktivitas pekerjaan yang dibuat oleh karyawan. Sehingga diharapkan proses pengerjaan proyek dapat ter-monitoring dengan baik serta mempermudah dan mempercepat proses penilaian kinerja karyawan yang dilakukan oleh manajemen.

Beberapa penelitian terdahulu yang terkait dengan penelitian ini antara lain penelitian yang dilakukan oleh Asti Herliana dan Prima Muhammad Rasyid (2016) dengan judul "Sistem Informasi Monitoring Pengembangan Software Pada Tahap Development Berbasis Web" [2]. Pada penelitian tersebut dibahas mengenai permasalahan yang terjadi dimana sulitnya untuk melihat data perkembangan proyek yang dilakukan karena pencatatan proyek yang sedang atau akan dikerjakan masih menggunakan spreadsheet dari program Microsoft Excel. Dengan menggunakan metode Waterfall menghasilkan sistem informasi monitoring perkembangan proyek berbasis web yang dapat digunakan untuk memantau proyek tanpa harus datang ke lokasi proyek. Persamaan permasalahan dalam kesulitan melakukan monitoring proyek menjadikan penelitian ini sebagai rujukan peneliti. Namun terdapat perbedaan pada penelitian yang dilakukan ini dimana terdapat fitur untuk melakukan pelaporan aktivitas pekerjaan oleh karyawan yang terintegrasi dengan data proyek serta terdapat fitur untuk melakukan evaluasi dan penilaian kinerja karyawan, sedangkan pada penelitian sebelumnya tidak ada fitur tersebut.

Penelitian lain yang dilakukan oleh Handrie Noprisson dan Budiyarti (2018) dengan judul "Aplikasi Manajemen Pemeliharaan Perangkat Lunak" [6] yang membahas tentang permasalahan dalam mengelola data permintaan pengelolaan perangkat lunak dan menghasilkan sebuah sistem berbasis web yang dapat menyediakan layanan untuk mengelola data perangkat lunak. Penelitian tersebut dijadikan acuan peneliti dalam menyediakan rancangan antarmuka sistem yang dapat digunakan untuk mengelola data proyek pengembangan perangkat lunak. Terdapat perbedaan dari penelitian yang dilakukan dengan penelitian ini yaitu pada penelitian sebelumnya menggunakan metode Prototype, sedangkan pada penelitian yang dilakukan peneliti menggunakan metode Waterfall.

Penelitian lain yang dilakukan oleh Rauf Fauzan dan Irpan Bangga Nugraha (2017) dalam penelitian "Pembangunan Aplikasi Task Management dalam Mendukung Proyek Pengembangan Perangkat Lunak (Studi Kasus: PT.eBdesk Indonesia)" [7] yang membahas mengenai sulitnya dalam melakukan pengawasan pegawai ketika pembuatan aplikasi perangkat lunak. Dengan menggunakan metode pengembangan Prototype menghasilkan sistem informasi task management yang dapat memberikan informasi secara cepat, dan akurat serta relevan dan tepat waktu agar dapat membantu proses monitoring dan pengerjaan proyek. Penelitian tersebut memberikan gambaran kepada peneliti dalam membuat sistem monitoring proyek yang dapat digunakan sebagai Task Management. Perbedaan dengan penelitian yang dilakukan dengan penelitian ini yaitu pada penelitian sebelumnya menggunakan metode Prototype, sedangkan pada penelitian yang dilakukan peneliti menggunakan metode Waterfall.

Penelitian yang dilakukan oleh Tegar Nugroho, Milan Putra, Ade Eka Asukma dan Riad Sahara (2018) dengan judul penelitian "A Web-Based Application for Leave and Employee Performance Appraisal (Case Study: PT. Dua Empat Tujuh)" [8] membahas mengenai penggunaan metode konvensional dalam melakukan penilaian kerja yang memakan waktu lama, dimana proses pengisian dokumen penilaian, pengumpulan data penilaian dan perhitungan akhir penilaian kerja karyawan dilakukan secara manual. Dengan menggunakan metode perancangan Rapid Application Development (RAD) penelitian tersebut menghasilkan sebuah sistem berbasis web yang dapat menyediakan layanan untuk pembuatan penilaian kerja tahunan karyawan. Persamaan permasalahan dalam melakukan penilaian kerja karyawan menjadikan penelitian tersebut sebagai rujukan peneliti dalam membuat sistem yang dapat digunakan untuk membuat penilaian kinerja karyawan. Namun terdapat perbedaan dengan penelitian yang dilakukan, dimana pada penelitian sebelumnya menggunakan metode $\mathrm{RAD}$, sedangkan pada penelitian ini menggunakan metode Waterfall. Selain itu proses penilaian yang dilakukan pada penelitian sebelumnya hanya berdasarkan penilaian objektif dari manajemen. Sedangkan pada penelitian ini, proses penilaian kinerja juga didasari oleh perhitungan performa karyawan didalam menyelesaikan tugas pekerjaan pada suatu proyek.

Penelitian oleh Ramos Somya (2018) dengan judul "Aplikasi Manajemen Proyek Berbasis Framework CodeIgniter dan Bootstrap di PT. Pura Barutama"[9] membahas tentang pendataan aktivitas pengerjaan proyek yang tidak akurat dan tidak dapat diakses secara real time. Dengan menggunakan metode Waterfall penelitian ini menghasilan perancangan dan implementasi aplikasi manajemen proyek menggunakan framework CodeIgniter dan Bootstrap untuk mempermudah proses manajemen proyek yang dapat diakses secara real time. Penelitian tersebut dijadikan rujukan peneliti dalam merancang dan membangun sistem monitoring proyek karena dengan menggunakan framework CodeIgniter dan Bootstrap dapat mempermudah dalam pembuatan sistem aplikasi berbasi web.

Perbedaan mendasar dari penelitian ini dengan penelitian sebelumnya adalah terdapat fasilitas untuk melakukan penilaian kinerja karyawan yang terintegrasi dengan data aktivitas pengembangan proyek sehingga proses verifikasi dan rekapitulasi data pekerjaan karyawan dapat dilakukan secara otomatis oleh sistem. Selain itu didalam sistem ini juga terdapat reminder sistem kepada karyawan apabila terdapat aktivitas terbaru didalam sebuah proyek yang sedang ditangani serta pemberitahuan apabila tugas proyek mendekati deadline.

\section{Metode Penelitian}

Dalam penelitian ini, terdapat beberapa tahapan yang dilakukan yaitu merumuskan masalah, penentuan tujuan, studi pustaka, melakukan pengumpulan data dan informasi, melakukan analisis sistem berjalan, melakukan perancangan dan implementasi sistem serta membuat kesimpulan.

ISSN : :2301-7988

E-ISSN : 2581-0588

DOI : $10.32736 /$ sisfokom.v8i2.634 


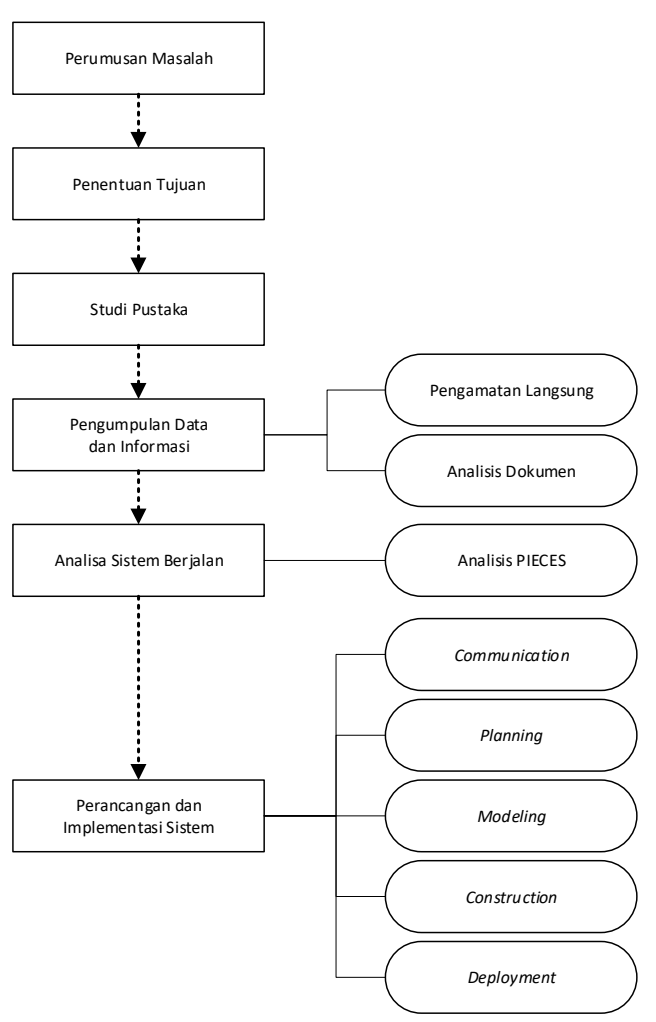

Gambar 1. Diagram Alir Penelitian

\section{A. Perumusan Masalah}

Pada tahap ini dilakukan peninjauan ke sistem yang akan diteliti untuk mengamati dan menggali permasalahan yang ada pada sistem yang berjalan saat ini pada PT. Jaguar Technology. Tahap perumusan masalah merupakan langkah awal dari penelitian ini, karena tahap ini diperlukan untuk mendefinisikan tujuan dari sistem yang tidak tercapai.

\section{B. Penentuan Tujuan}

Berdasarkan perumusan masalah yang telah dibuat pada tahap sebelumnya, maka tahap penentuan tujuan berguna untuk memperjelas apa saja yang menjadi sasaran dari penelitian ini. Pada tahap ini juga ditentukan tujuan dari penelitian yaitu untuk merancang dan mengimplementasikan suatu sistem informasi berbasis web yang dapat mendukung kegiatan monitoring proyek dan penilaian kinerja karyawan pada PT. Jaguar Technology.

\section{Studi Pustaka}

Studi pustaka dilakukan dengan maksud untuk mengetahui metode apa yang dapat digunakan untuk menyelesaikan permasalahan yang akan diteliti, serta mendapatkan dasardasar referensi yang kuat bagi peneliti dalam menerapkan suatu metode yang digunakan.

\section{Pengumpulan Data dan Informasi}

Pada tahap ini dilakukan pengumpulan data dan informasi untuk lebih mengetahui mengenai sistem yang diteliti. Datadata dan informasi diperoleh melalui pengamatan langsung serta melihat dan menganalisis dokumen-dokumen yang terkait dengan alur proses proyek pengembangan sistem yang sedang berjalan di PT. Jaguar Technology. Adapun data-data yang diperlukan dalam penelitian ini adalah:

- Jenis aktivitas yang ada dalam proyek pengembangan sistem pada PT. Jaguar Technology.

- Alur dari proses pengerjaan proyek pengembangan sistem yang dilakukan.

- Form pengisian Job Report yang diisi oleh karyawan dalam melakukan pelaporan aktivitas pekerjaan.

- Dokumen hasil rekapitulasi Job Report yang digunakan sebagai bahan penilaian kinerja karyawan.

- Dokumen penilaian kinerja karyawan.

\section{E. Analisa Sistem Berjalan}

Tahap analisa sistem merupakan suatu prosedur yang dilakukan untuk mengidentifikasi permasalahan dan melakukan penyusunan alternatif pemecahan masalah yang timbul serta membuat spesifikasi sistem yang baru atau sistem yang akan diusulkan dan dimodifikasi[10]. Pada proses ini bertujuan untuk mengidentifikasi permasalahan yang ada pada sistem yang digunakan di Divisi Solution Infrastructure Business (SIB)-Banking Solution saat ini, dalam melakukan monitoring proyek dan penilaian kinerja karyawan. Analisa yang digunakan dalam penelitian ini adalah metode PIECES (Performance, Information, Economics, Control, Efficiency, Service) guna memperoleh pokok-pokok permasalahan yang lebih spesifik dengan membandingkan antara sistem lama dengan sistem yang diusulkan. Perbandingan dilakukan terhadap beberapa aspek antara lain adalah kinerja, informasi, ekonomi, keamanan aplikasi, efisiensi dan pelayanan pelanggan.

\section{F. Perancangan dan Implementasi Sistem}

Dalam proses perancangan dan pengembangan sistem, peneliti menggunakan metode Waterfall (Pressman, 2010) [11] yang dimulai dari mengumpulkan dan menentukan kebutuhan pengguna (communication), perencanaan (planning), pemodelan (modeling), kontruksi (construction) hingga diakhiri dengan dukungan berkelanjutan pada aplikasi yang dihasilkan (deployment).

\section{Communication}

Langkah ini merupakan tahap pengumpulan data serta informasi tambahan sebagai bahan analisa mengenai kebutuhan sistem berdasarkan permasalahan yang ada pada sistem berjalan

\section{Planning}

Proses planning merupakan kelanjutan dari proses communication. Dalam tahap ini dilakukan perencanaan waktu pelaksanaan pengembangan sistem yang akan dilakukan yaitu selama dua bulan.

3. Modeling

Melakukan analisa dan pemodelan sistem berdasarkan kebutuhan yang telah ditentukan sebelumnya. Pemodelan yang dilakukan berupa diagram-diagram alur sistem yang nantinya menjadi acuan dalam pengembangan sistem. Perancangan sistem yang dilakukan menggunakan pemodelan berorientasi object yaitu Unifield Mode Language (UML) yang 
meliputi pembuatan Use Case Diagram, Activity Diagram, dan Class Diagram.

4. Construction

Merupakan tahapan pembuatan sistem dalam bentuk kode-kode program berdasarkan rancangan yang telah dibuat. Bahasa pemograman berbasis web yang digunakan adalah PHP dengan framework CodeIgniter dan Bootstrap. Tahap implementasi sistem merupakan salah satu prosedur yang dilakukan untuk menyelesaikan desain perancangan sistem dan melakukan uji coba atas konsep pengembangan sistem yang telah disusun guna memastikan apakah konsep yang telah disusun dapat dilaksanakan dengan baik atau tidak[10].

5. Deployment

Tahapan ini merupakan tahapan terakhir dalam pembuatan sistem. Setelah sistem selesai dibuat, maka sistem tersebut akan digunakan oleh user. Kemudian sistem tersebut akan dilakukan pemeliharaan secara berkala.

\section{HASIL DAN PEMBAHASAN}

\section{A. Analisa Sistem Berjalan}

Sistem yang berjalan pada proses monitoring proyek di PT Jaguar Technology menggunakan sistem berbasis web yang digunakan sebagai kanal untuk melakukan pencatatan data proyek. Proses pelaporan aktivitas karyawan (Job Report) dilakukan dengan menggunakan aplikasi Microsoft Excel yang tidak terintegrasi dengan data proyek pada sistem, sehingga Project Administrator perlu untuk melakukan pendataan daftar proyek dan melakukan rekapitulasi kembali laporan tersebut sebelum menyerahkan kepada manajemen. Selain itu proses penilaian kinerja karyawan yang dilakukan manajemen juga dilakukan secara konvensional menggunakan data Microsoft Excel yang rentan terjadi manipulasi data.

\section{Proses Bisnis Sistem Berjalan}

Berikut ini merupakan alur dari proses bisnis yang dilakukan pada sistem berjalan

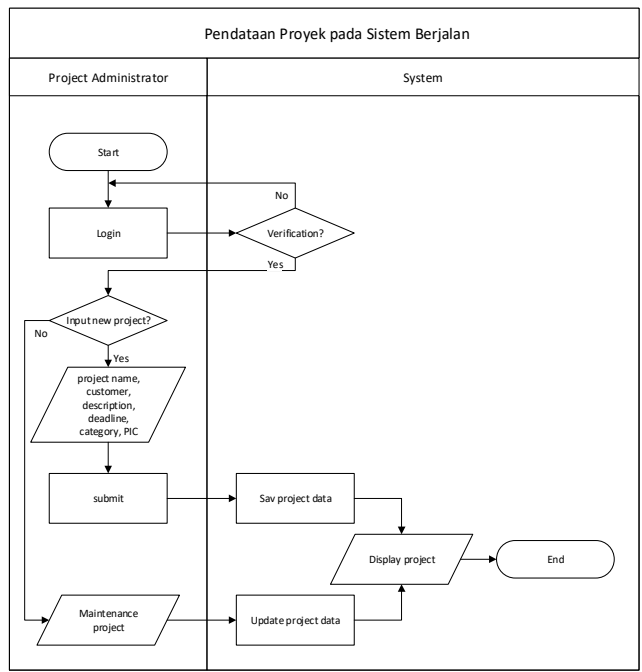

Gambar 2. Alur proses pendataan proyek pada sistem berjalan
Pada gambar 2 menjelaskan tentang alur proses pendataan proyek pada sistem berjalan, dimana Project Administrator harus login ke dalam aplikasi web yang ada untuk melakukan input baru atau maintenance terhadap data proyek yang ada. Jika Project Administrator melakukan input proyek baru, maka Project Administrator akan memasukan informasi yang berhubungan dengan proyek tersebut. Setelah data tersimpan, maka sistem akan menampilkan data proyek yang baru saja dibuat. Jika Project Administrator melakukan maintenance proyek, maka Compliance akan memasukan data terbaru dari perkembangan proyek yang ada. Setelah data tersimpan, maka sistem akan menampilkan data proyek yang baru saja dilakukan pengkinian.

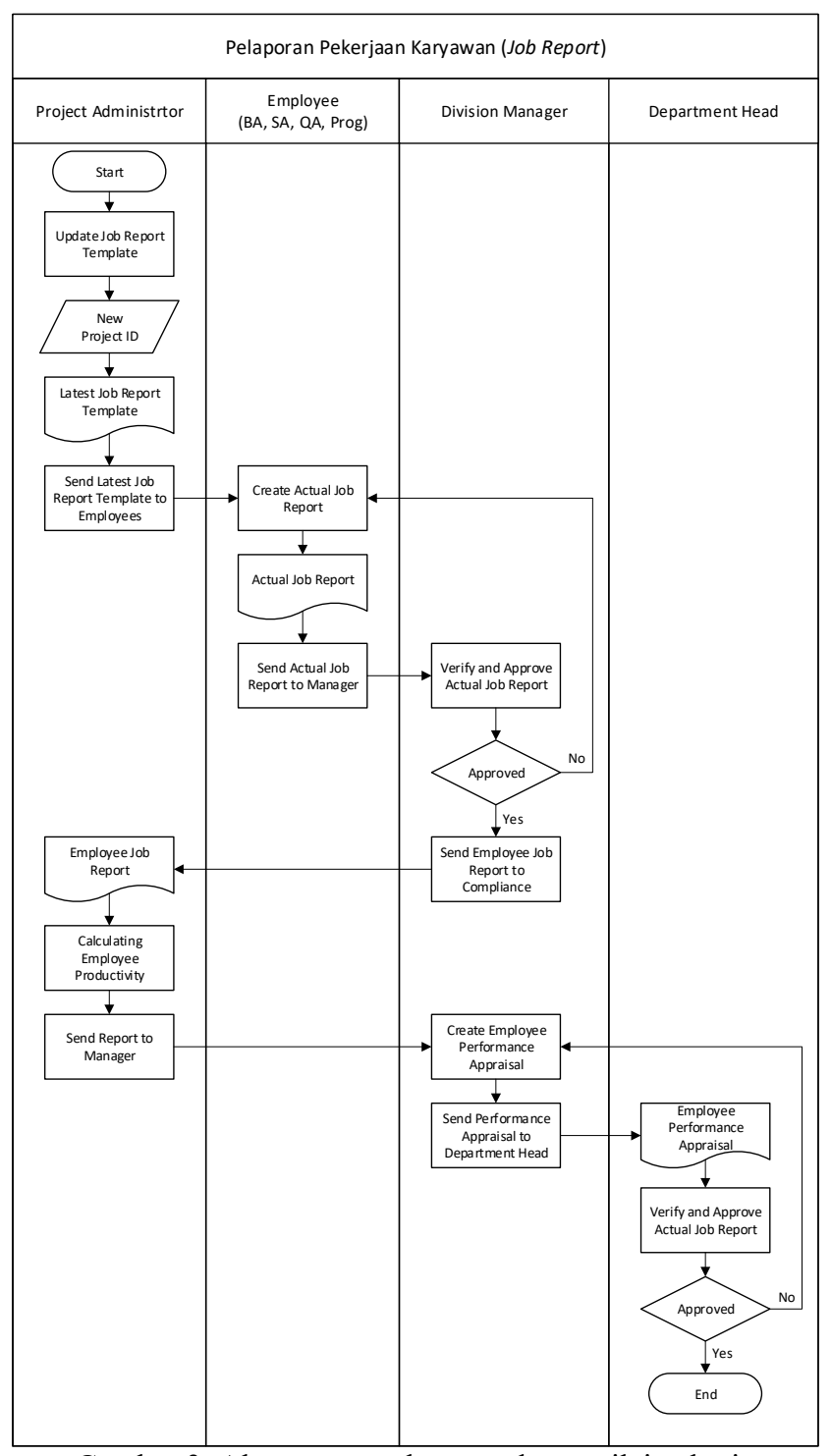

Gambar 3. Alur proses pelaporan dan penilaian kerja karyawan

ISSN : 2301-7988

E-ISSN : 2581-0588

DOI : $10.32736 /$ sisfokom.v8i2.634 
Pada gambar 3 menjelaskan alur proses pelaporan pekerjaan danpenilaian kinerja karyawan pada sistem berjalan, dimana Project Administrator melakukan pengkinian template laporan kerja dalam bentuk file Microsoft Excel dengan mendaftarkan PID baru yang belum terdaftar pada template sebelumnya. Kemudian template laporan kerja terbaru tersebut akan dikirimkan kepada seluruh karyawan melalui email. Selanjutnya karyawan akan mengisi template laporan kerja tersebut sesuai dengan aktivitas pekerjaan yang sudah selesai dilakukan dalam bentuk Actual Job Report secara periodik dua minggu sekali. Actual Job Report karyawan tersebut selanjutnya akan dikirimkan ke Manager untuk diverifikasi Manager akan melakukan verifikasi terhadap Actual Job Report karyawan. Jika laporan kerja sudah sesuai, maka Manager akan mengirimkan data tersebut ke Project Administrator. Jika ada ketidaksesuaian terhadap laporan kerja yang dikirim oleh karyawan, maka manager akan meminta karyawan untuk memperbaiki kembali Actual Job Report tersebut. Project Administrator akan melakukan rekapitulasi laporan kerja karyawan dengan menggunakan aplikasi Microsoft Excel untuk menghitung tingkat pemakaian mandays/manhours karyawan terhadap proyek yang dikerjakan. Hasil perhitungan tersebut kemudian akan diserahkan kepada Manager sebagai bahan pembuatan laporan evaluasi kinerja karyawan (Performance Appraisal). Performance Appraisal tersebut selanjutnya akan dikirimkan ke Department Head. Department Head akan melakukan verifikasi terhadap data Performance Appraisal, jika data tersebut terdapat kesalahan maka Department Head akan meminta Manager untuk memperbaiki data tersebut.

\section{Use Case Sistem Berjalan}

Use case merupakan pemodelan utama yang mendefinisikan perilaku didalam sebuah sistem. Use case menggambarkan bagaimana interaksi pengguna dengan sistem untuk melakukan beberapa aktivitas[12]. Berdasarkan analisa proses bisnis pada sistem berjalan, didapatkan gambaran interaksi aktor dengan sistem sebagai berikut.

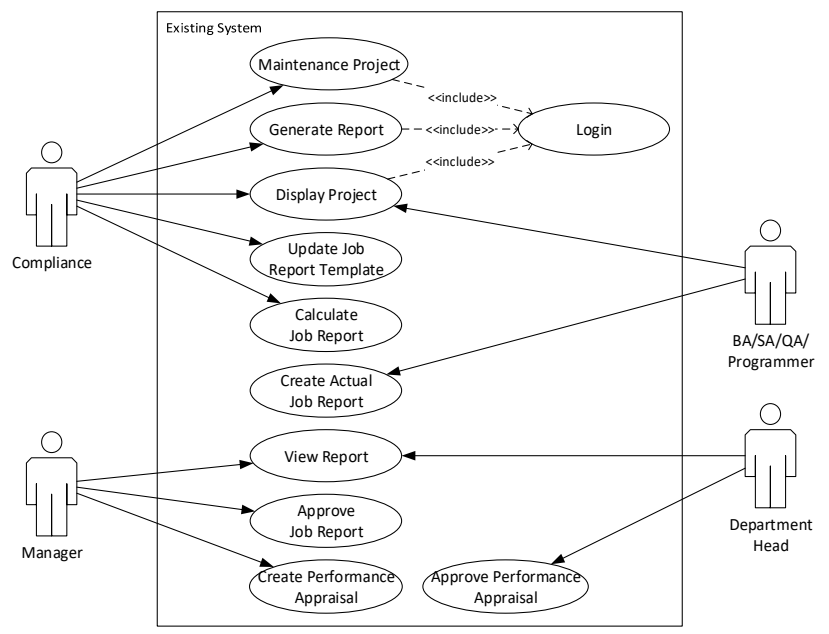

Gambar 4. Use Case Sistem Berjalan

\section{B. Identifikasi Masalah}

Dalam penggunaan sistem tersebut ditemukan beberapa permasalahan yang menyebabkan monitoring proyek dan pelaporan aktivitas karyawan belum bisa dilakukan dengan baik, diantaranya sebagai berikut:

1. Pencatatan aktivitas proyek pada sistem berjalan dilakukan dengan menggunakan kolom detail proyek dan hanya dapat dilakukan oleh Compliance / Project Administrator membuat pengelolaan data proyek menjadi tidak maksimal.

2. Pengisian informasi batas akhir (deadline) dari suatu proyek hanya sebatas informasi tambahan karena tidak ada validasi ataupun reminder sistem kepada PIC proyek tersebut, hal tersebut menyebabkan seringkali terdapat aktivitas proyek yang melewati batas akhir atau bahkan belum ditindaklanjuti

3. Pengisian form laporan kerja (Job Report) yang tidak terintegrasi dengan data proyek pada aplikasi membuat Compliance harus melakukan update template Job Report secara berkala untuk mendata Project ID baru.

4. Rekapitulasi laporan kerja dengan menggunakan aplikasi Microsoft Excel memakan banyak waktu karena data laporan pekerjaan karyawan berada di data yang berbedabeda berdasarkan periode pelaporan.

5. Proses penilaian kinerja karyawan dilakukan secara konvensional menggunakan data Microsoft Excel sehingga rentan terjadi manipulasi data yang dapat merugikan perusahaan.

\section{Analisa Kebutuhan}

Berdasarkan identifikasi permasalahan yang ada, maka dibutuhkan sebuah sistem yang memiliki karakteristik sebagai berikut:

a. Sistem dapat melakukan pengelolaan data proyek yang meliputi pembuatan data proyek baru, melakukan perubahan data proyek yang sudah ada maupun melakukan penghapusan data proyek.

b. Sistem dapat menyediakan fitur untuk melakukan pengkinian perkembangan proyek yang sedang dilakukan.

c. Sistem dapat menyediakan fitur reminder terhadap proyek yang akan memasuki batas akhir pengerjaan maupun yang sudah melewati batas pengerjaan proyek.

d. Sistem dapat menampilkan laporan job load dari tiaptiap karyawan yang ada.

e. Sistem dapat menyediakan fitur untuk melakukan pelaporan aktivitas pekerjaan karyawan yang terintegrasi dengan data proyek.

f. Sistem dapat menampilkan laporan jumlah jam kerja yang sudah dilakukan oleh karyawan.

g. Sistem dapat menampilkan laporan kinerja karyawan sebagai bahan evaluasi manajemen.

\section{Analisis PIECES}

Berikut ini merupakan pemaparan analisa PIECES 
(Performance, Information, Economic, Control, Efficiency, Service) berdasarkan perbedaan antara sistem lama dengan sistem yang akan diusulkan, diantaranya.

1. Performance

Pada sistem berjalan, pengkinian perkembangan proyek hanya dilakukan oleh Project Administrator dan pengisian data pekerjaan pada form penilaian kinerja karyawan dilakukan secara manual oleh Manager dengan mengecek rekapitulasi laporan pekerjaan yang telah dibuat oleh Project Administrator cukup memakan waktu

Sedangkan pada sistem usulan, pengkinian perkembangan proyek dapat dilakukan oleh seluruh karyawan yang terlibat didalam proyek dan data pekerjaan karyawan akan secara otomatis terbentuk didalam sistem berdasarkan data pada laporan pekerjaan karyawan yang telah dibuat.

2. Information

Pada sistem berjalan, informasi proyek sulit untuk diolah karena semua informasi tambahan proyek tersebut hanya dapat dicatat pada kolom deskripsi. History data aktivitas proyek tidak terdokumentasi dengan baik karena laporan kerja masih disimpan di local PC yang terpisah. Berdasarkan pengamatan, karyawan tidak selalu mengirimkan informasi terbaru kepada project administrator sehingga perkembangan terbaru dari suatu proyek pada sistem menjadi tidak akurat.

Sedangkan pada sistem usulan, detail informasi proyek memiliki isian masing-masing sesuai dengan subjek informasi yang dibutuhkan. History data aktivitas proyek tersimpan didalam sistem dan terintegrasi dengan data proyek. Pelapoan kerja karyawan dilakukan setiap hari dengan validasi pada sistem sehingga informasi mengenai perkembangan proyek akan lebih cepat diperoleh.

3. Economic

Pada sistem berjalan, terdapat biaya konsumsi yang dikeluarkan untuk mengadakan rapat mingguan dalam rangka mengumpulkan informasi perkembangan proyek.

Sedangkan pada sistem usulan, biaya konsumsi dapat dihilangkan karena informasi perkembangan proyek dapat dilakukan secara langsung didalam sistem dan dapat langsung dilihat oleh semua pengguna yang memiliki akses.

4. Control

Pada sistem berjalan, monitoring terhadap proyek dilakukan secara manual dengan melihat informasi detail proyek secara berkala pada sistem maupun dengan melihat catatan pada data rekap Excel. Verifikasi data pada penilaian kinerja karyawan dilakukan dengan mengecek data rekap Excel yang rentan terjadi manipulasi data.

Sedangkan pada sistem usulan, monitoring proyek dapat dilihat pada dashboard sistem berupa informasi mengenai batas waktu pengerjaan proyek serta terdapat notifikasi ketika proyek sudah mendekati batas akhir pengerjaan. Selain itu data penilaian kinerja karyawan akan secara otomatis dihimpun berdasarkan data laporan pekerjaan karyawan yang dibuat oleh karyawan pada sistem.

5. Efficiency
Pada sistem berjalan, pengkinian data perkembangan proyek hanya dapat dilakukan oleh project administrator menyebabkan informasi perkembangan proyek menjadi lambat ketika terdapat banyak proyek yang harus ditangani secara bersamaan. Pelaporan aktivitas pekerjaan karyawan dilakukan dengan menggunakan Microsoft Excel yang tidak terintegrasi dengan data proyek, menyebabkan project administrator harus melakukan pembaruan data project ID pada template laporan kerja. Serta proses rekapitulasi dan perhitungan kinerja karyawan dilakukan secara manual menggunakan aplikasi Microsoft Excel memakan waktu cukup lama.

Sedangkan pada sistem usulan, pengkinian data perkembangan aktivitas proyek dapat dilakukan oleh seluruh karyawan yang terlibat, sehingga informasi perkembangan proyek dapat diperoleh secara lebih cepat. Pelaporan kerja karyawan dilakukan pada sistem, sehingga data project ID akan terintegrasi dengan laporan kerja karyawan. Serta proses rekapitulasi dan perhitungan kinerja karyawan dilakukan secara otomatis pada sistem sehingga project administrator tidak perlu melakukan perhitungan manual kembali.

6. Service

Pada sistem berjalan, terbatasnya jumlah project administrator menyebabkan pelayanan pengkinian status proyek dari PIC proyek hanya dapat ditangani secara terbatas.

Sedangkan pada sistem usulan, semua PIC proyek dapat melakukan pengkinian status perkembangan proyek secara mandiri, sehingga project administrator dapat melakukan aktivitas pelayanan yang lain

\section{E. Perancangan Sistem Usulan}

Pada tahapan perancangan sistem usulan, peneliti menjabarkan dalam bentuk use case diagram, activity diagram dan class diagram.

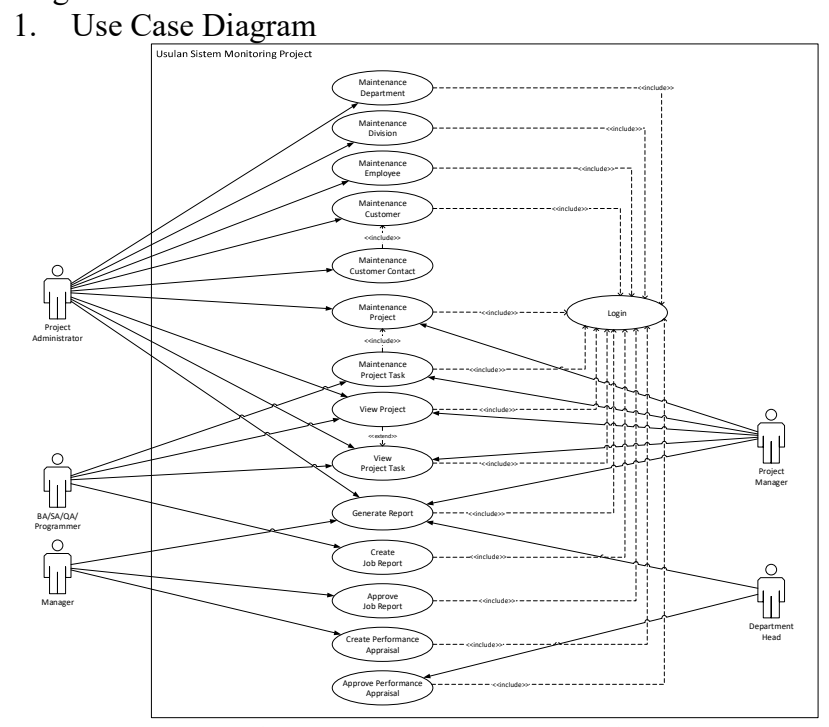

Gambar 5 Use Case Sistem Usulan

ISSN : 2301-7988

E-ISSN : 2581-0588

DOI : $10.32736 /$ sisfokom.v8i2.634 


\section{Activity Diagram}

Activity diagram digunakan untuk menggambarkan alur kerja atau perilaku didalam proses bisnis yang tidak bergantung pada object[12].

Dibawah ini merupakan activity diagram yang terdapat pada sistem monitoring aktivitas proyek.

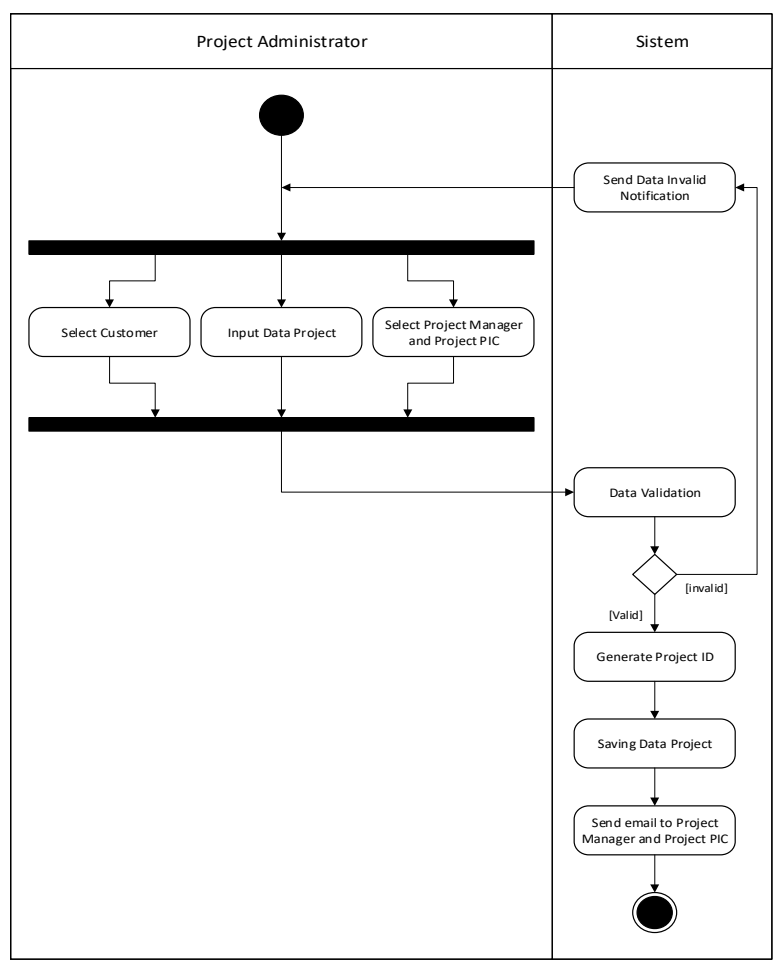

Gambar 6. Activity Add Project

Gambar 6 menunjukan proses dari aktivitas menambahkan data proyek yang dapat dilakukan oleh Project Administrator. Project Administrator dapat melakukan penambahan data proyek dengan memasukan informasi data customer, data proyek, data project manager serta data PIC dari proyek yang sedang dikerjakan. Jika data yang dimasukan valid, maka sistem akan membentuk Project ID sebagai nomor unik identifikasi proyek tersebut.

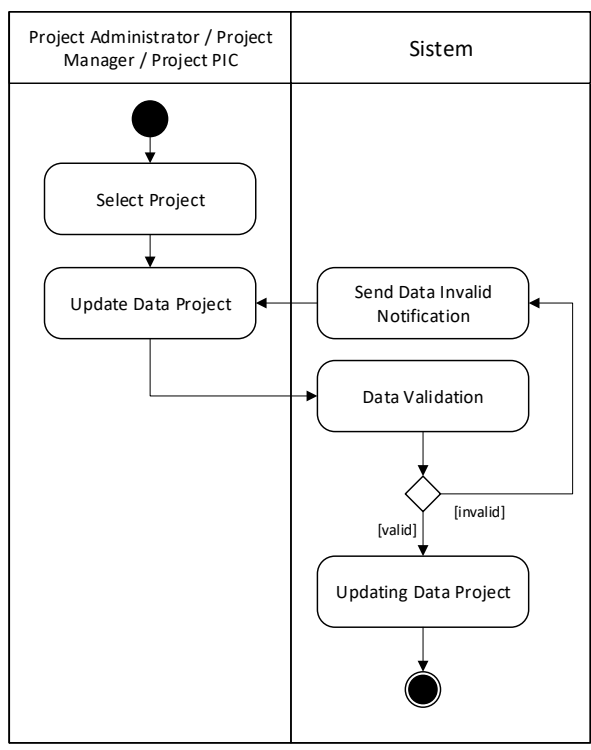

Gambar 7. Activity Update Project

Gambar 7 menunjukan proses dari aktivitas pengkinian data proyek yang dapat dilakukan oleh Project Administrator, Project Manager atau PIC Proyek yang ditunjuk.

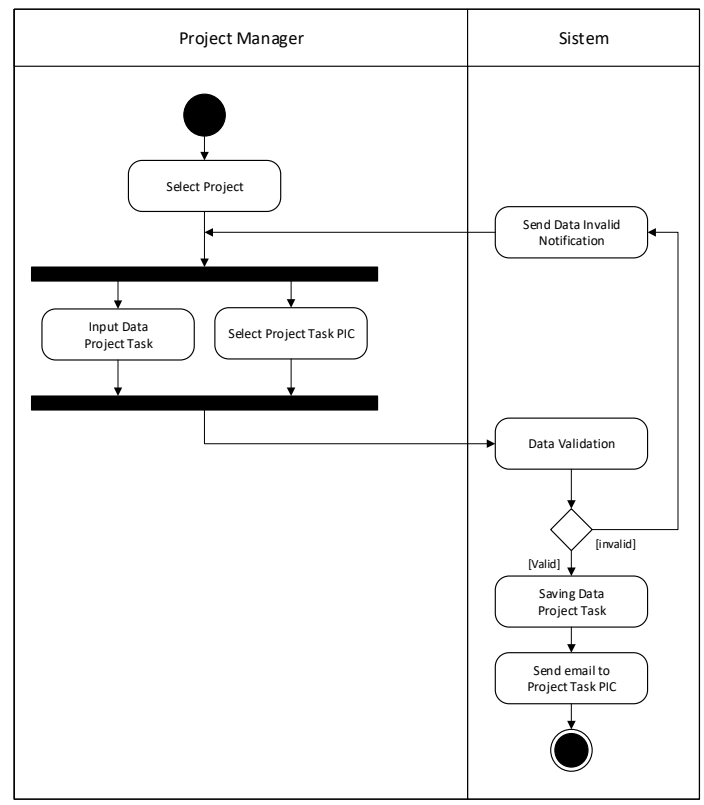

Gambar 8. Activity Add Project Task

Gambar 8 menunjukan proses dari aktivitas menambahkan data penugasan proyek baru yang dapat dilakukan oleh Project Manager. Project manager akan memilih data proyek yang akan dilakukan penugasan, kemudian mengisi data tugas proyek dan memilih PIC yang ditugaskan. Jika data valid, maka sistem akan mengirimkan notifikasi kepada PIC yang ditunjuk mengenai detail dari penugasan yang diberikan. 


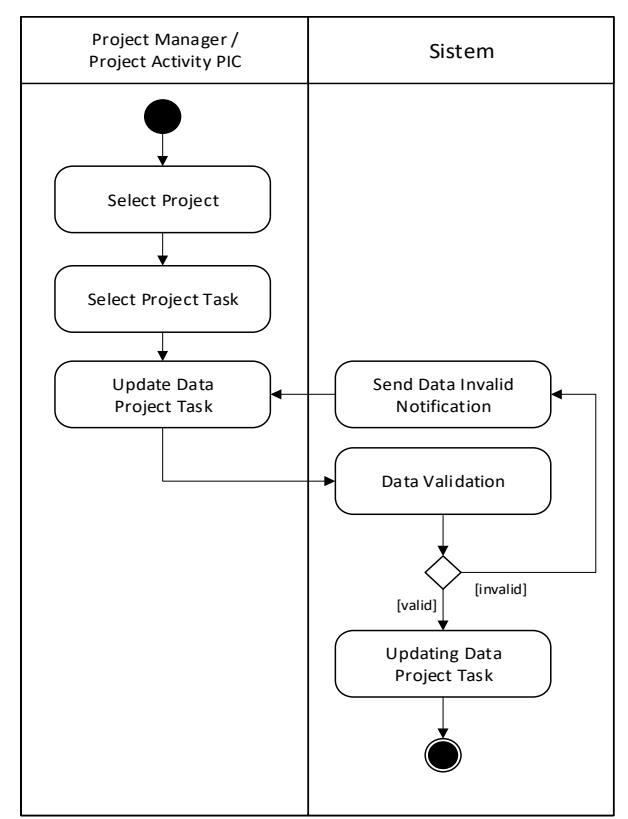

Gambar 9. Activity Update Project Task

Gambar 9 menunjukan proses dari aktivitas pengkinian data tugas proyek yang dapat dilakukan oleh Project Manager atau PIC Proyek yang ditunjuk.

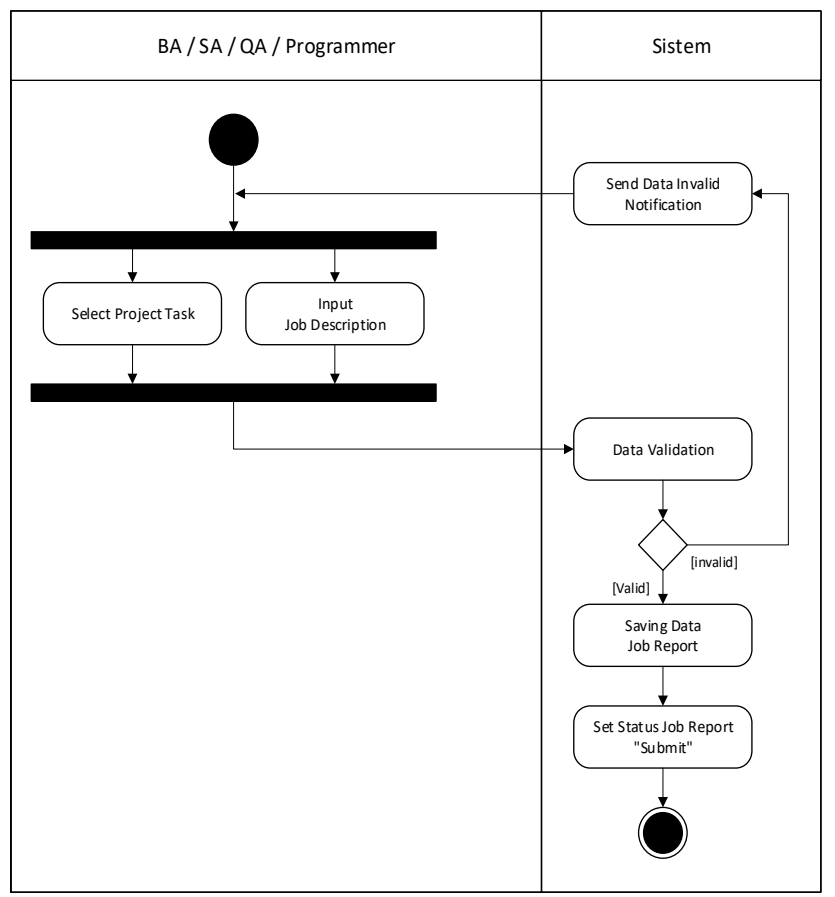

Gambar 10. Activity Create Job Report

Gambar 10 menunjukan proses dari aktivitas pembuatan laporan pekerjaan yang dapat dilakukan oleh karyawan. Proses pelaporan pekerjaan dilakukan dengan memilih data tugas proyek dan mengisi deskripsi/detail pekerjaan yang sudah selesai dilakukan. Jika data yang dimasukan valid, maka laporan tersebut akan secara otomatis terkirim kepada manager karyawan untuk diverifikasi.

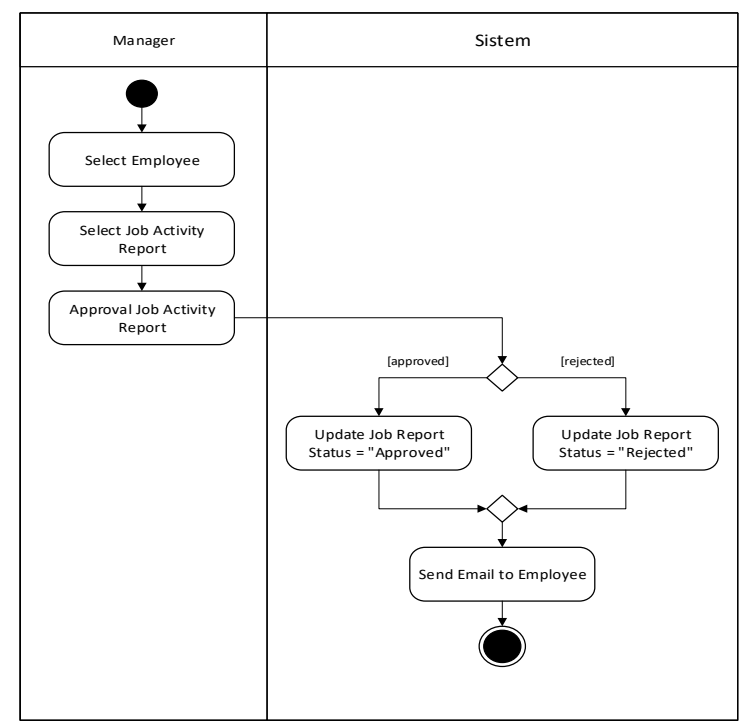

Gambar 11. Activity Approval Job Report

Gambar 11 menunjukan proses dari aktivitas approval laporan pekerjaan karyawan yang dapat dilakukan oleh manager. Manager dapat melakukan approve maupun reject terhadap laporan yang telah dikirimkan oleh karyawan. Karyawan akan mendapatkan notifikasi ketika laporan pekerjaannya selesai diverifikasi oleh manager.

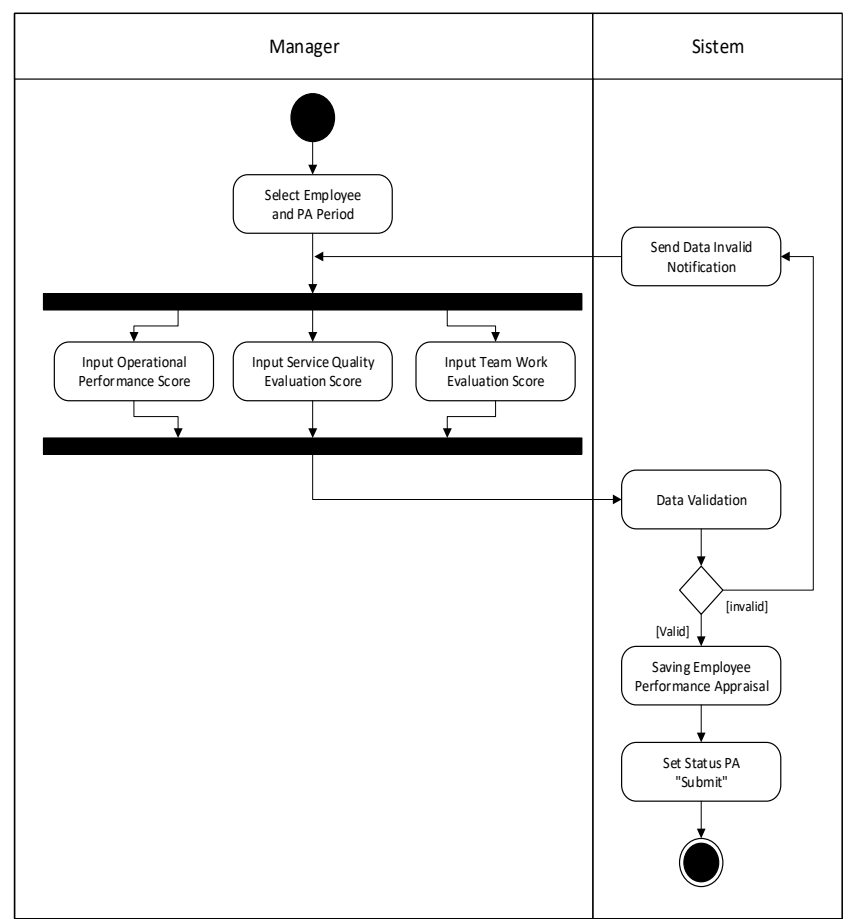

Gambar 12. Activity Create Performance Appraisal 
Gambar 12 menunjukan proses dari aktifitas pembuatan penilaian kinerja karyawan yang dapat dilakukan oleh manager karyawan. Manager akan melakukan pengisian nilai pada tiga kategori penilaian yaitu Operational Performance, Service Quality Evaluation dan Team Work Evaluation. Pada kategori Operational Performance, sistem akan secara otomatis menghimpun data aktivitas pekerjaan yang telah dilakukan oleh karyawan dan menampilkan informasi tersebut pada antarmuka sebagai bagian dari bahan penilaian yang dilakukan Manager untuk kategori penilaian tersebut.

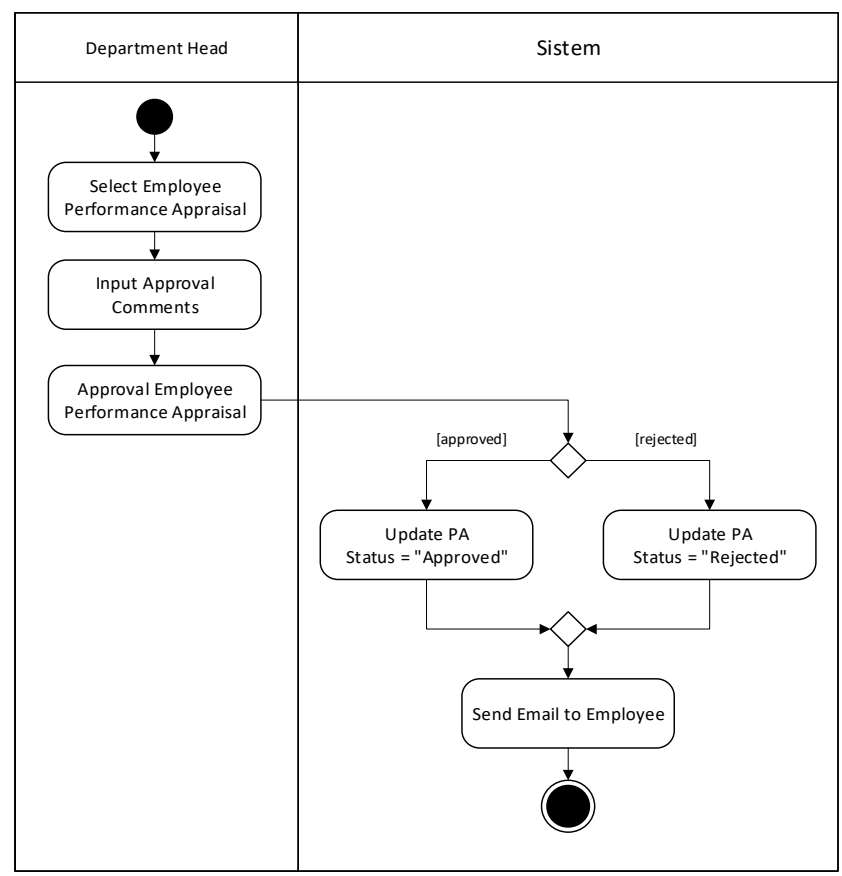

Gambar 13. Activity Approval Performance Appraisal

Gambar 13 menunjukan proses dari aktivitas approval penilaian kinerja karyawan yang dilakukan oleh Department Head. Department Head dapat melakukan approve maupun reject terhadap data penilaian yang telah dikirimkan oleh manager karyawan. Karyawan akan mendapatkan notifikasi ketika laporan pekerjaannya selesai diverifikasi oleh Department Head.

\section{Class Diagram}

Class diagram merupakan mode statis yang mendukung gambaran statis dari class dan hubungan antar class yang konstan didalam sebuah sistem dari waktu ke waktu[13]. Berikut ini merupakan class diagram yang terdapat didalam usulan sistem monitoring proyek.

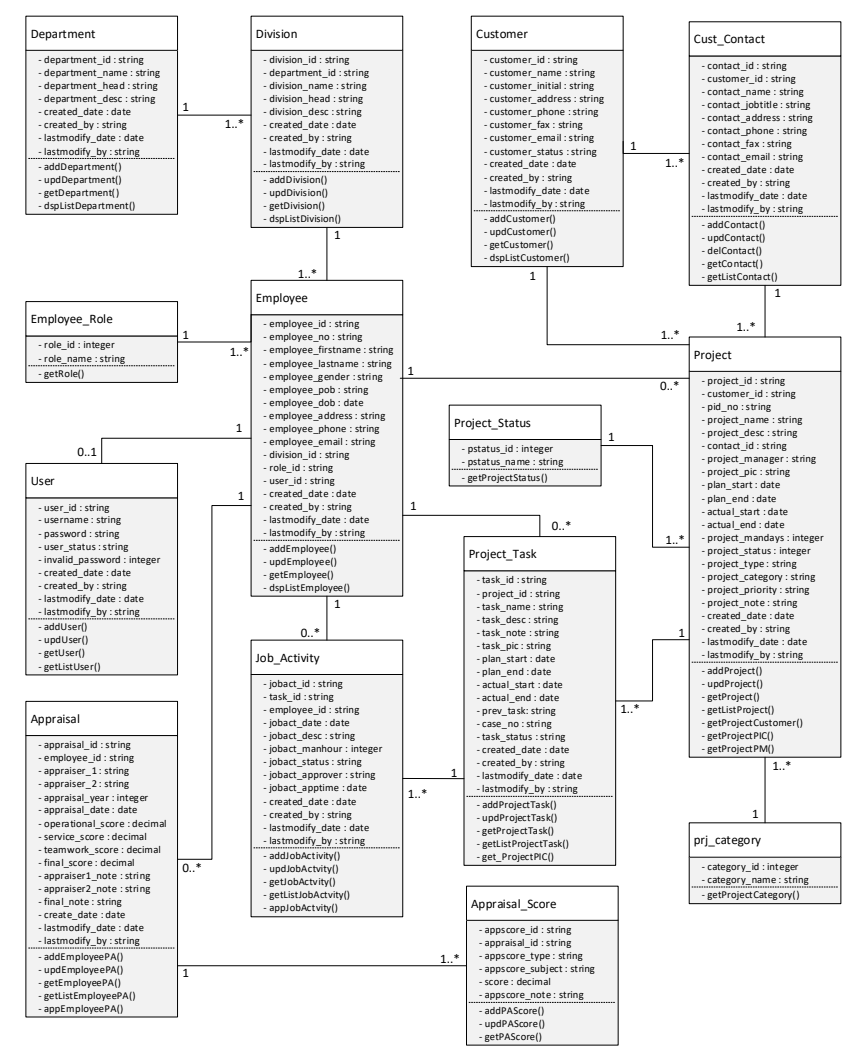

Gambar 14. Class Diagram Sistem Usulan

\section{F. Implementasi Sistem}

Tahap implementasi sistem merupakan salah satu prosedur yang dilakukan untuk menyelesaikan desain perancangan sistem dan melakukan uji coba atas konsep pengembangan sistem yang telah disusun guna memastikan apakah konsep yang telah disusun dapat dilaksanakan dengan baik atau tidak (Sutabri,2012) [10].

\section{Halaman Utama}

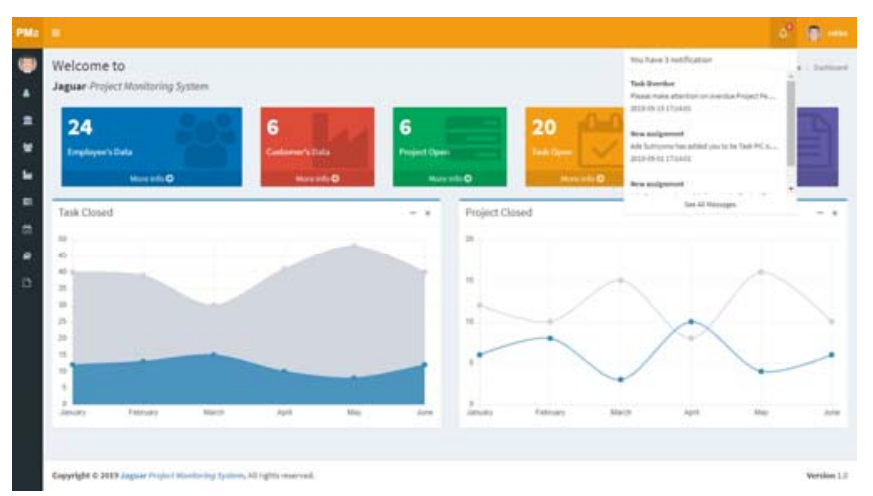

Gambar 15. Halaman Utama

Gambar 15 menunjukan halaman utama User yang berisi rangkuman informasi yang terdapat pada sistem monitoring 
proyek. Selain itu pada halaman utama juga terdapat panel notifikasi user mengenai informasi aktivitas yang terkait dengan tugas pekerjaan user tersebut.

\section{Halaman Detail Data Proyek}

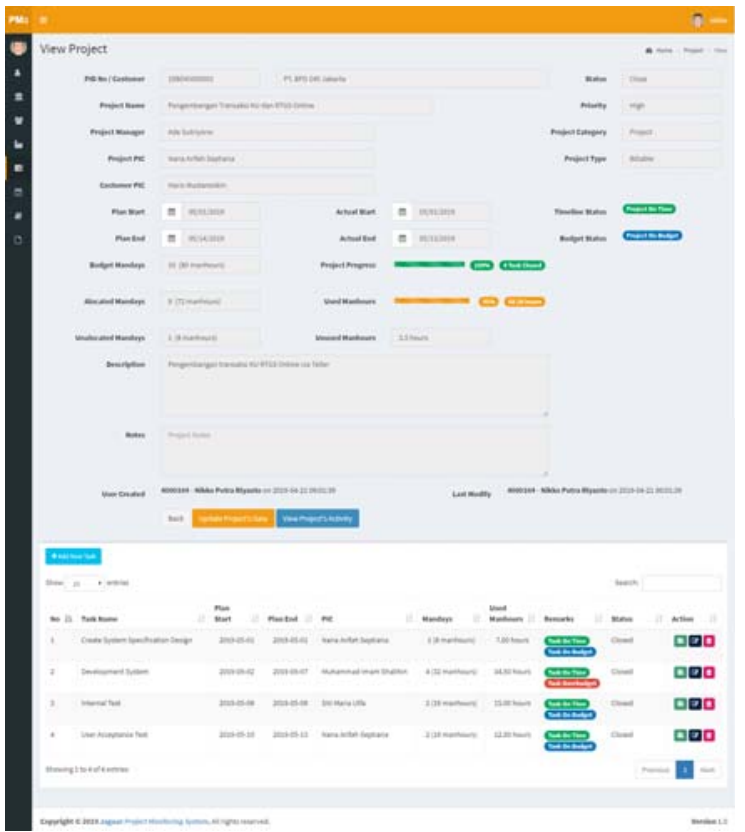

Gambar 16. Halaman Detail Data Proyek

Gambar 16 merupakan tampilan halaman detail data proyek yang berisi informasi lengkap sebuah proyek. Informasi yang terdapat pada halaman ini diantaranya status pengerjaan proyek, progress aktivitas proyek, progress pemakaian manhour proyek, data penugasan proyek, data PIC proyek dan dokumen pendukung proyek dalam bentuk lampiran yang dapat didownload oleh user.Halaman Ubah Data Proyek

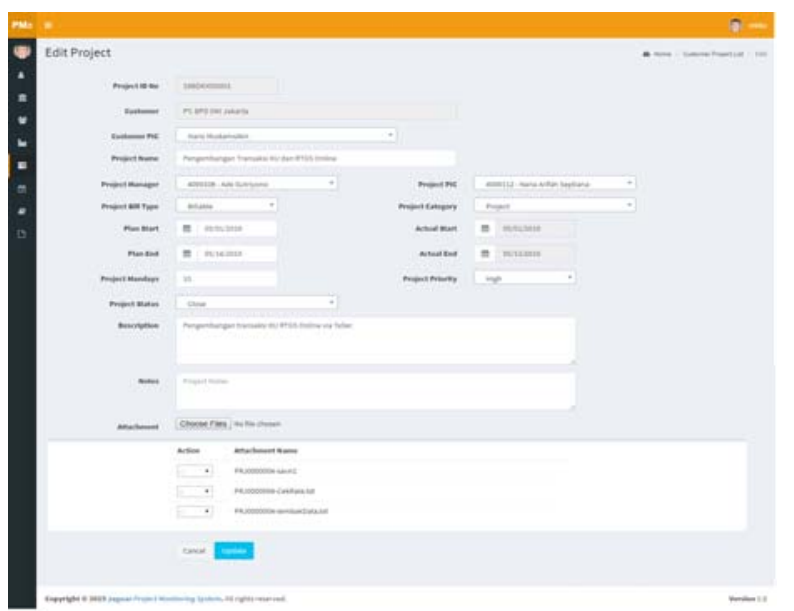

Gambar 17. Halaman Ubah Data Proyek

Gambar 17 menunjukan halaman untuk melakukan pengkinian data proyek. User dapat melakukan pembaruan data maupun status dari proyek yang sedang dikerjakan.

3. Halaman Input Laporan Pekerjaan Karyawan

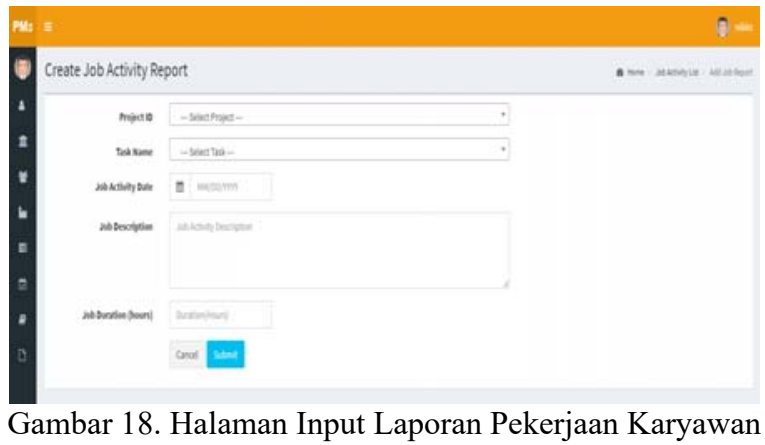

Gambar 18 merupakan halaman pengisian data laporan pekerjaan yang telah selesai dikerjaan oleh karyawan. Karyawan akan memilih tugas proyek yang akan dilaporkan, kemudian mengisi detail pekerjaan yang dikerjakan beserta waktu dan durasi pekerjaan yang dilakukan.

4. Halaman Approval Laporan Pekerjaan Karyawan

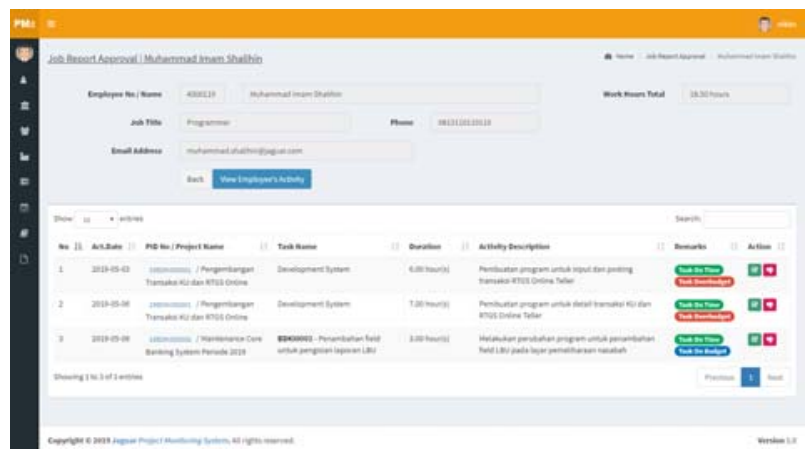

Gambar 19. Halaman Approval Laporan Pekerjaan Karyawan

Gambar 19 merupakan halaman approval laporan pekerjaan yang telah dikirimkan oleh karyawan. User dapat melakukan approve atau reject terhadap data laporan pekerjaan yang telah dibuat.

5. Halaman Aktivitas Proyek

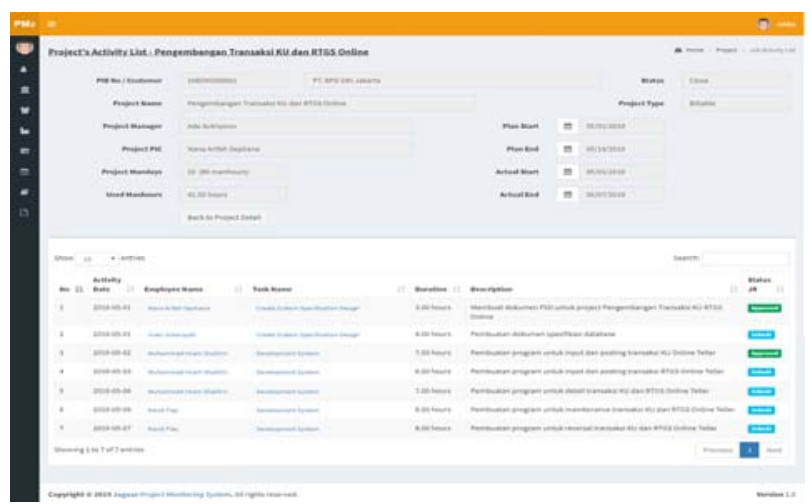

Gambar 20. Halaman Aktivitas Proyek 
Gambar 20 merupakan halaman informasi aktivitas pekerjaan proyek yang berisi rincian daftar aktivitas pekerjaan karyawan didalam sebuah proyek. Informasi tersebut dihimpun berdasarkan laporan pekerjaan yang telah diisi oleh karyawan.

6. Halaman Input Penilaian Kinerja Karyawan

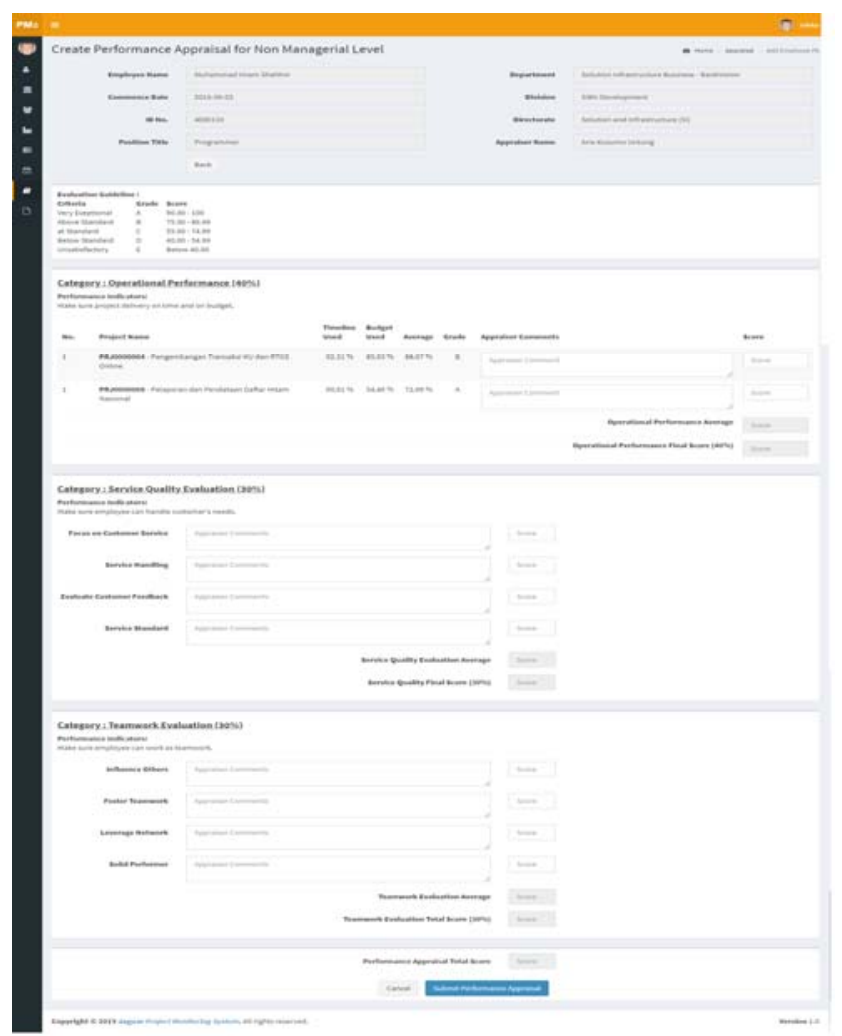

Gambar 21. Halaman Input Penilaian Kinerja Karyawan

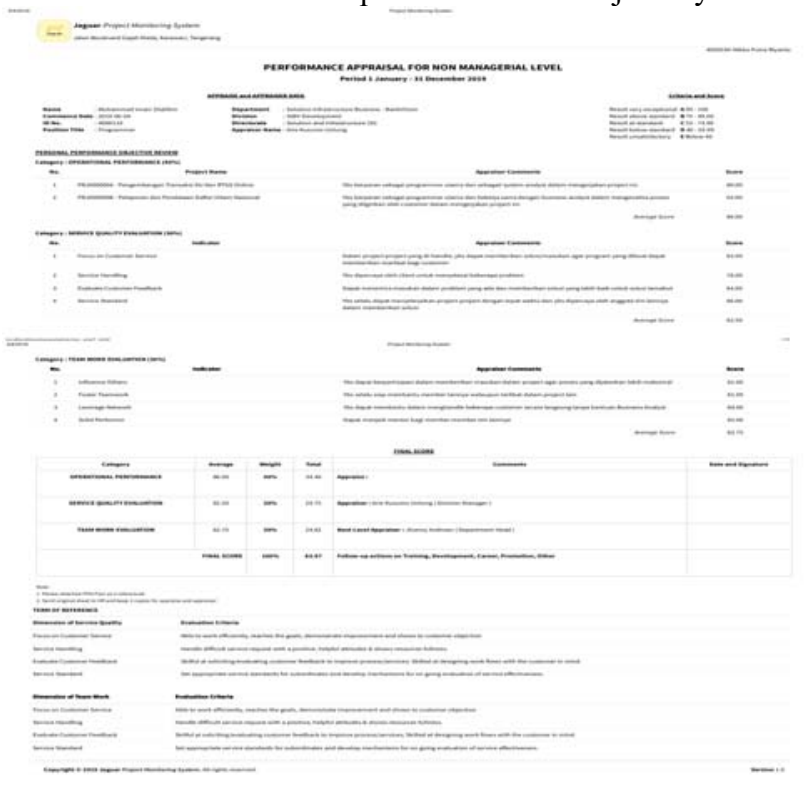

Gambar 22. Laporan Penilaian Kinerja Karyawan
Gambar 21 merupakan halaman pengisian data penilaian kinerja karyawan, terdapat tiga kategori penilaian yaitu Operational Performance, Service Quality Evaluation dan Team Work Evaluation. Pada kategori Operational Performance akan otomatis terisi daftar pekerjaan yang telah dilakukan oleh karyawan. Sedangkan pada gambar 22 merupakan hasil laporan penilaian kinerja karyawan yang dapat diunduh oleh user pada sistem.

\section{KESIMPULAN}

Berdasarkan proses analisa dan pembahasan yang telah dilakukan pada penelitian ini dapat disimpulkan bahwa sistem lama yang digunakan saat ini pada PT. Jaguar Technology masih belum dapat mengakomodir proses monitoring proyek dengan baik sehingga dibutuhkan sebuah sistem baru yang dapat digunakan untuk mengatasi permasalahan yang ada. Dengan adanya Sistem Monitoring Proyek yang diusulkan ini, proses pengkinian perkembangan proyek yang sebelumnya hanya dapat dilakukan oleh Project Administrator kini bisa dilakukan juga oleh PIC proyek. Kemudian semua perkembangan proyek yang dilaporkan karyawan melalui laporan pekerjaan didalam sistem akan terintegrasi dengan data proyek, sehingga pencarian data historis aktivitas proyek dapat dengan mudah dilakukan serta memudahkan pihak manajemen dalam melakukan verifikasi data sebagai bahan untuk penilaian kinerja karyawan.. Sistem Monitoring Aktivitas Proyek ini juga memudahkan karyawan dalam membuat laporan pekerjaan harian dan menghilangkan pekerjaan Project Administrator dalam melakukan rekapitulasi laporan kerja yang sebelumnya dilakukan secara konvensional dengan Microsoft Excel.

\section{DAFTAR PUSTAKA}

[1] P. M. Institute, A Guide to the Project Management Body of Knowledge, 5th ed. Project Management Institute, Inc., 2013.

[2] A. Herliana and P. M. Rasyid, "Sistem Informasi Monitoring Pengembangan Software pada Tahap Development Berbasis Web," J. Inform., vol. 3, no. 1, pp. 41-50, 2016.

[3] M. Manullang, Dasar-Dasar Manajemen. Yogyakarta: Gajah Mada University Press, 2012.

[4] I. Ranggadara and R. Sahara, "Analytical Hierarchy Process Algorithm Approach for Determining Best Employee (Case Study IT Company in Jakarta)," Int. J. Comput. Sci. Mob. Comput., vol. 6, no. 12 , pp. 59-64, 2017.

[5] A. Abraham, Performance Appraisal. Hamburg: Anchor Academic Publishing, 2014.

[6] H. Noprisson and Budiyarti, "Aplikasi Manajemen Pemeliharan Produk Perangkat Lunak," J. Sci. Appl. Informatics, vol. 1, no. 2, pp. 41-45, 2018.

[7] R. Fauzan and I. B. Nugraha, "Pembangunan Aplikasi Task Management Dalam Mendukung Proyek Pengembangan Perangkat Lunak (Studi Kasus: PT. eBdesk Indonesia)," J. Terap. Teknol. Inf., vol. 1, no. 2, pp. 131-141, 2017.

[8] T. Nugroho, M. Putra, A. E. Asukma, P. Andreas, and R. Sahara, “A Web-Based Application for Leave and Employee Performance Appraisal ( Case Study : PT . DUA EMPAT TUJUH ),” vol. 7, no. 11, pp. 92-104, 2018.

ISSN $\quad: 2301-7988$

E-ISSN : 2581-0588

DOI $\quad: 10.32736 /$ sisfokom.v8i2.634 


=

[9] R. Somya, "Aplikasi Manajemen Proyek Berbasis Framework CodeIgniter dan Bootstrap di PT. Pura Barutama," J. Inform. J. Pengemb. IT, vol. 3, no. 2, pp. 143-150, 2018.

[10] T. Sutabri, Konsep Sistem Informasi. Yogyakarta: Penerbit Andi, 2012.

[11] R. S. Pressman, Software Engineering A Practitioner's Approach 7th Edition. 2010
[12] A. Dennis, B. H. Wixom, and D. Tegarden, System Analysis Design UML Version 2.0, 4th ed. Don Fowley, 2012.

[13] A. Dennis, B. H. Wixom, and R. M. Roth, System Analysis and Design, 5th ed. John Wiley \& Sons, Inc., 2012.

ISSN : 2301-7988

E-ISSN : 2581-0588

DOI : $10.32736 /$ sisfokom.v8i2.634 